\title{
Detecção e classificação molecular de Chlamydophila psittaci em amostras fecais de aves assintomáticas
}

\author{
[Detection and molecular characterization of Chlamydophila psittaci \\ in asymptomatic birds]
}

\author{
M.A. Braz, D.C. Silva, M.E.B. Santiago, S.D. Garcia, A.A. Nakamura, M.V. Meireles*
}

Universidade Estadual Paulista - Faculdade de Medicina Veterinária - Araçatuba, SP

\begin{abstract}
RESUMO
Chlamydophila psittaci é uma bactéria que causa doença respiratória ou sistêmica em aves e em seres humanos. Em vista do risco de transmissão para humanos, o objetivo deste estudo foi detectar a presença de Chlamydophila spp. em amostras de fezes ou suabes cloacais de aves assintomáticas. Foram colhidas 403 amostras fecais ou suabes cloacais, provenientes de aves domésticas, selvagens ou exóticas. As amostras foram submetidas à PCR em tempo real para C. psittaci, para amplificação de fragmento parcial do gene da subunidade 16S do rRNA, utilizando o SsoFast ${ }^{\text {TM }}$ EvaGreen ${ }^{\circledR}$ Supermix (Bio-Rad) e análise da curva de dissociação. Para determinação do genótipo de C. psittaci, foi usada a hemi-nested PCR visando à amplificação de fragmento parcial do gene OMP-A, realizada nas amostras positivas pela PCR em tempo real, seguida de sequenciamento dos fragmentos amplificados. A PCR em tempo real revelou positividade em $17(4,21 \%)$ amostras. A hemi-nested foi positiva em 2 amostras positivas pela PCR em tempo real. O genótipo A de C. psittaci foi identificado pelo sequenciamento de uma amostra amplificada pela hemi-nested PCR. Os resultados deste experimento demonstram que a PCR em tempo real, visando à amplificação de fragmento parcial da subunidade 16S do rRNA, seguida da análise da curva de dissociação, pode ser utilizada para detecção de DNA de Chlamydophila sp. em amostras fecais de aves assintomáticas. A classificação da espécie de Chlamydophila e do genótipo de C. psittaci deve ser realizada por meio de PCR tendo como alvo o gene ompA e sequenciamento dos fragmentos amplificados.
\end{abstract}

Palavras-Chave: aves, psitacose, diagnóstico molecular, zoonoses

\begin{abstract}
Chlamydophila psittaci is a bacterium that causes respiratory or systemic disease in birds and humans. Owing to the risk of transmission from asymptomatic birds to humans, the objective of this study was to detect the presence of Chlamydophila spp. in asymptomatic birds. Four hundred and three fecal samples or cloacal swabs were collected from domestic, wild or exotic birds. The 403 samples were examined by real time PCR specific for the $16 S$ subunit of rRNA gene using SsoFastEvaGreen ${ }^{\circledR}$ Supermix ${ }^{\mathrm{TM}}$ (Bio-Rad) and melting curve analysis. Hemi-nested PCR specific for the OMP-A gene, accomplished in real-time $P C R$ positive samples, was followed by sequencing of the amplified fragments to determine the genotype of C. psittaci. Real-time PCR was positive in 17 (4.21\%) samples. Hemi-nested PCR revealed positivity in two samples previously positive by real-time PCR. Sequencing of the fragment amplified by hemi-nested $P C R$ allowed for the identification of genotype A of C. psittaci in one sample. The results of this experiment show that the real-time PCR targeting the 16S rRNA gene followed by melting curve analysis can be used for diagnosis of Chlamydophila sp. in fecal samples of asymptomatic birds. The classification of the Chlamydophila species and the genotype of $\mathrm{C}$. psittaci must be accomplished by PCR targeting the ompA gene and sequencing of the amplified fragments.
\end{abstract}

Keywords: birds, psittacosis, molecular diagnostic, zoonoses

Recebido em 31 de outubro de 2012

Aceito em 17 de julho de 2013

*Autor para correspondência (corresponding author)

E-mail: marcelo@fmva.unesp.br 


\section{INTRODUÇÃO}

Considerada como uma das principais zoonoses aviárias (Proença et al., 2011), a infecção por Chlamydophila psittaci é caracterizada por doença respiratória ou sistêmica em aproximadamente 465 espécies de aves (Kaleta e Taday, 2003). No homem, é responsável por infecção respiratória decorrente de contato direto ou indireto com aves infectadas, particularmente psitacídeos, pombos, perus ou patos (Hedberg et al., 1989; Hinton et al., 1993).

A transmissão da clamidiose ocorre por meio de inalação do agente em suspensão, após contato direto ou indireto com fezes, penas ou secreções respiratórias, embora a infecção oral seja uma rota alternativa e importante em aves (Shewen, 1980). Aves portadoras assintomáticas apresentam períodos intermitentes de excreção de pequena quantidade da bactéria; a reativação da eliminação é favorecida por fatores, como estresse, subnutrição, extremos de temperatura e cativeiro (Harkinezhad et al., 2009).

A infecção por $C$. psittaci em humanos pode ser assintomática ou apresentar sintomatologia inespecífica, principalmente relacionada ao trato respiratório (Stewardson e Grayson, 2010). Indivíduos com ocupações associadas às aves comerciais ou de companhia são considerados como grupo de risco para infecção por C. psittaci (Miller et al., 1987).

A identificação de Chlamydophila spp. pode ser realizada utilizando-se testes sorológicos, como o ensaio imunoenzimático (ELISA), e métodos moleculares, como a reação em cadeia da polimerase (PCR) seguida da análise do polimorfismo de fragmentos amplificados, submetidos à digestão com enzimas de restrição (PCR-RFLP), PCR e sequenciamento e PCR em tempo real (Vanrompay et al., 1997; Geens et al., 2005a).

C. psittaci atualmente é constituída por sete genótipos aviários (A, B, C, D, E, F e E/B) e dois genótipos não aviários (M56 e WC). A determinação do genótipo de $C$. psittaci é realizada por meio de análise da sequência de nucleotídeos do gene que codifica a proteína da parede externa (ompA) (Geens et al., 2005b).
Tendo em vista o risco de transmissão para humanos a partir de aves assintomáticas, o objetivo deste trabalho foi detectar $C$. psittaci em amostras de fezes e de suabes cloacais de aves assintomáticas, por meio da PCR em tempo real e, posteriormente, nas amostras positivas, identificar o genótipo de $C$. psittaci por meio da hemi-nested PCR seguida de sequenciamento do fragmento amplificado.

\section{MATERIAL E MÉTODOS}

O desenvolvimento deste trabalho foi aprovado pela Comissão de Ética no Uso de Animais CEUA - da FOA/UNESP em 17/11/2010, de acordo com o protocolo 2010-008742.

As amostras foram provenientes de aves assintomáticas de um criatório de psitacídeos (57) e de dois zoológicos municipais (183), no estado de São Paulo, e de aves selvagens apreendidas e encaminhadas ao Centro de Triagem e Recuperação de Animais Silvestres (CERETAS), da Faculdade de Medicina Veterinária da UNESP de Araçatuba (163). As aves pertencem às ordens Accipritriformes, Anseriformes, Caprimulgiformes, Charadriiformes, Galiiformes, Gruiformes, Passeriformes, Piciformes, Psitaciformes e Strigiformes (Tab. $1)$.

Tabela 1. Amostras positivas para Chlamydophila sp. pela PCR em tempo real

\begin{tabular}{lcc} 
Ordem & $\begin{array}{c}\text { Número } \\
\text { de } \\
\text { amostras }\end{array}$ & $\begin{array}{c}\text { Amostra } \\
\text { positivas }\end{array}$ \\
\hline Psitaciformes & 348 & 16 \\
Piciformes & 18 & 1 \\
Gruiformes & 3 & - \\
Anseriformes & 12 & - \\
Passeriformes & 11 & - \\
Accipitriformes & 2 & - \\
Strigiformes & 3 & - \\
Galliformes & 2 & - \\
Charadiiformes & 3 & - \\
Caprimulgiformes & 1 & - \\
\hline Total & 403 & 17 \\
\hline
\end{tabular}

Foram colhidas 403 amostras, sendo que 199 correspondiam a suabes cloacais e 204 eram amostras fecais. As amostras fecais foram colhidas imediatamente após a defecação e, logo após a colheita, foram armazenadas em 
temperatura ambiente, por no máximo uma semana, em microtubos de $2,0 \mathrm{~mL}$ contendo o tampão L6 (Triton X100 1\%, Tris-Cl pH 6,4 0,1 $\mathrm{M}$, isotiocianato de guanidina $4 \mathrm{M}$ ); os suabes cloacais foram congelados a $-20^{\circ} \mathrm{C}$. A extração de DNA genômico de Chlamydophila foi realizada de acordo com Silva et al. (2010).

A PCR em tempo real para amplificação de um fragmento de $151 \mathrm{pb}$ da subunidade $16 \mathrm{~S}$ do rRNA de $C$. psittaci foi realizada utilizando os oligonucleotídeos iniciadores CpPsSSfor e CpPsSSrev, descritos por Geens et al. (2005a) (Tab. 2). A reação foi padronizada por meio de determinação da curva de regressão padrão, utilizando como DNA um fragmento de $818 \mathrm{pb}$ da subunidade $16 \mathrm{~S}$ do rRNA de $C$. abortus cepa S23/3 (gentilmente cedido pela Professora Tânia de Freitas Raso, da FMVZ-USP), amplificado por meio de PCR convencional com os oligonucleotídeos iniciadores 16SFor e 16SRew (Tab. 2), que foram elaborados com utilização do software Primer Blast. O DNA de C. abortus foi utilizado para determinação da curva padrão pelo fato de que não havia disponibilidade de DNA de C. psittaci e porque, em avaliação prévia, apresentou amplificação positiva pela PCR em tempo real com utilização dos oligonucleotídeos iniciadores CpPsSSfor e CpPsSSrev.

Tabela 2. Oligonucleotídeos iniciadores utilizados na PCR convencional, na etapa de padronização da PCR em tempo real, e na PCR em tempo real e hemi-nested PCR, utilizadas para detecção ou classificação molecular de Chlamydophila em amostras fecais

\begin{tabular}{|c|c|c|c|c|c|}
\hline Reação & $\begin{array}{l}\text { Oligonucleotídeos } \\
\text { iniciadores }\end{array}$ & Sequência $5^{`}-3^{\prime}$ & Referência & $\begin{array}{l}\text { Gene- } \\
\text { alvo }\end{array}$ & $\begin{array}{l}\text { Produto } \\
\text { amplifi- } \\
\text { cado (pb) }\end{array}$ \\
\hline $\begin{array}{l}\text { Hemi- } \\
\text { nested } \\
\text { PCR }\end{array}$ & $\begin{array}{l}\text { CTU (reações } \\
\text { primária e } \\
\text { secundária) } \\
\text { Chla2 (reação } \\
\text { primária) } \\
\text { Chla3a (reação } \\
\text { secundária) }\end{array}$ & ATGAAAAAACTCTTGAAATCGG & $\begin{array}{l}\text { Denamur et } \\
\text { al. }(1991) \\
\text { este } \\
\text { experimento } \\
\text { este } \\
\text { experimento }\end{array}$ & ompA & $\begin{array}{c}1097 \\
\text { (reação } \\
\text { primária) } \\
644 \\
\text { (reação } \\
\text { secundária) }\end{array}$ \\
\hline
\end{tabular}

O fragmento amplificado pela PCR convencional foi submetido à eletroforese em gel de agarose, e o DNA foi purificado utilizando-se o QIAquick ${ }^{\circledR}$ Gel Extraction Kit (Qiagen) e diluído de forma seriada, na base 10 , a partir de $22 \mathrm{ng}$ de DNA, para obtenção de seis pontos na curva de regressão. Cada diluição foi testada em triplicata.

Após padronização da curva padrão, a PCR em tempo real foi realizada em amostras de DNA proveniente de aves, nas seguintes condições: $6,4 \mu 1$ de água ultrapura, $10 \mu 1$ de SsoFast $^{\mathrm{TM}}$ EvaGreen ${ }^{\circledR}$ Supermix (Bio-Rad), 0,8 $\mu 1$ de cada oligonucleotídeo iniciador (CpPsSSfor e CpPsSSrev) e $2 \mu 1$ de DNA-alvo. Foi utilizada desnaturação inicial de $98^{\circ} \mathrm{C}$ por 2 minutos, seguida de 44 ciclos de desnaturação a $95^{\circ} \mathrm{C}$, por
5 segundos, e anelamento e extensão a $60^{\circ} \mathrm{C}$, por 5 segundos. Após o término da amplificação, foi determinada a curva de dissociação do fragmento amplificado, com variação de temperatura de 65 a $95^{\circ} \mathrm{C}$, com intervalo de $0,2^{\circ} \mathrm{C}$ e leitura por 10 segundos. A reação foi realizada no sistema para PCR em tempo real CFX-96 (Bio-Rad). Água ultrapura foi utilizada em lugar de DNA-molde, em reações controle negativas, e DNA de $C$. abortus foi utilizado como molde em reaçõescontrole positivas.

Visando à identificação do genótipo de $C$. psittaci, em todas as amostras positivas pela PCR em tempo real foi realizada a amplificação de fragmentos do gene OmpA, utilizando a heminested PCR com os oligonucleotídeos iniciadores 
CTU (Denamur et al., 1991), Chla2 e Chla3, que foram elaborados com utilização do software Primer Blast (Tab. 2), nas seguintes condições: volume final de $25 \mu$ l de solução contendo $2,5 \mu \mathrm{l}$ de tampão para PCR 10x, $1,5 \mathrm{mM} \mathrm{MgCl}_{2}, 5 \mu \mathrm{g}$ /microlitro de albumina sérica bovina não acetilada, $200 \mathrm{nM}$ de cada oligonucleotídeo iniciador, 0,5U de Taq DNA polimerase, $0,2 \mathrm{mM}$ de cada desoxiribonucleotídeo e 2,5 $\mu 1$ de DNAalvo. As amostras foram submetidas à desnaturação inicial do DNA a $95^{\circ} \mathrm{C}$ por 2 minutos, seguida de 40 ciclos, cada um consistindo em desnaturação a $95^{\circ} \mathrm{C}$ por 30 segundos, 30 segundos de anelamento a $55^{\circ} \mathrm{C}$ e extensão a $72^{\circ} \mathrm{C}$ por 60 segundos, com extensão final a $72^{\circ} \mathrm{C}$, por 10 minutos. As condições foram as mesmas em ambas as reações. Como controles positivo e negativo, foram utilizadas amostras de DNA de C. abortus e água ultrapura, respectivamente.

O fragmento amplificado na reação secundária foi purificado utilizando-se o kit QIAquick ${ }^{\circledR} \mathrm{Gel}$ Extraction (Qiagen) e sequenciado no Centro de
Sequenciamento e Genômica Funcional da UNESP, Campus de Jaboticabal, utilizando o “ABI Prism ${ }^{\circledR}$ DyeTerminator 3.1", em sequenciador automático ABI 3730XL (Applied Biosystems). As reações de sequenciamento foram realizadas duas vezes, nas duas direções, com os oligonucleotídeos iniciadores da reação secundária. Os fragmentos resultantes do sequenciamento foram comparados com sequências homólogas publicadas no GenBank, com auxílio do Basic Local Alignment Search Tool (BLAST).

\section{RESULTADOS E DISCUSSÃO}

A curva padrão obtida após padronização da PCR em tempo real resultou em eficiência de $95,4 \%, \mathrm{R}^{2}$ : 0,99 e slope: $-3,4$. A amostra de DNA de $C$. abortus, utilizada como controle positivo, apresentou temperatura de dissociação 83,0 a $83,2^{\circ} \mathrm{C}$. A curva de dissociação do fragmento de DNA de C. psittaci, amplificado a partir das amostras fecais, apresentou temperatura de dissociação de 83,2 a $83,4^{\circ} \mathrm{C}$ (Fig. 1).

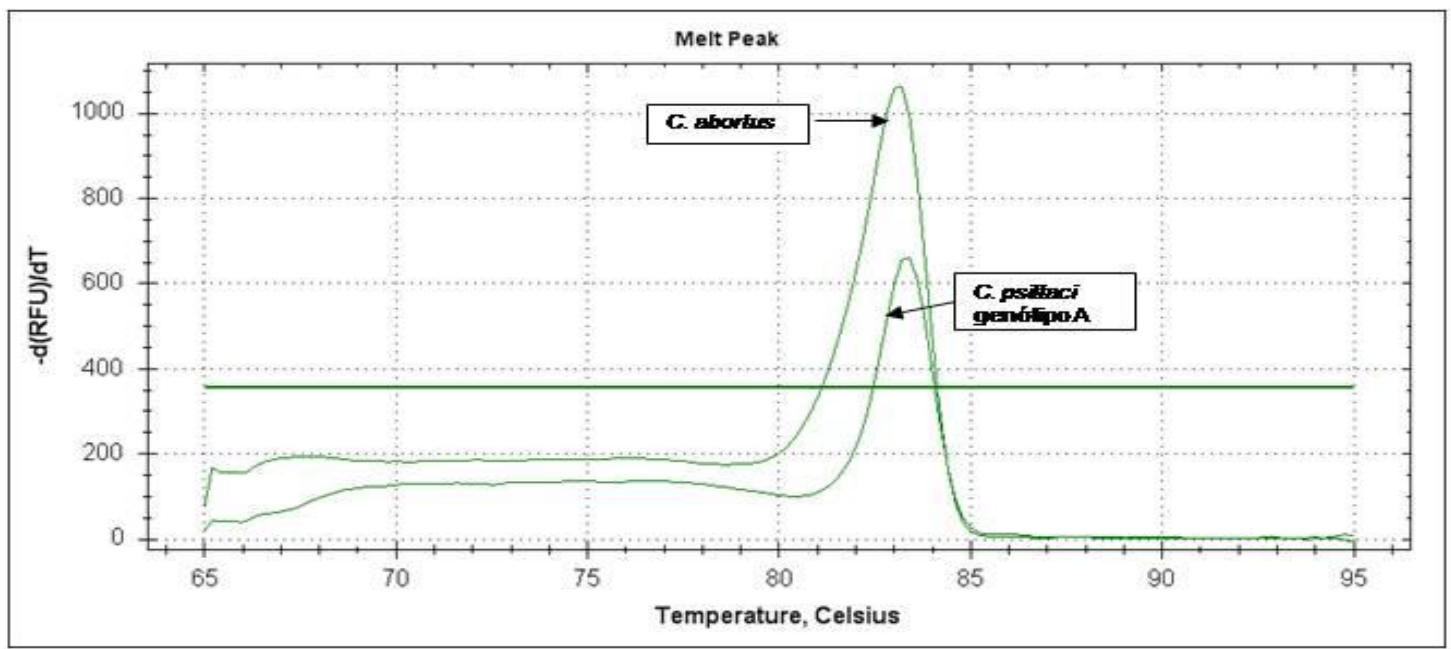

Figura 1. Curva de dissociação observada na PCR em tempo real para Chlamydophila abortus e Chlamydophila psittaci

Foi observada baixa prevalência de Chlamydophila, provavelmente pelo fato de que as aves não apresentavam sintomas da enfermidade e, também, porque foi possível a colheita de somente uma amostra por ave. Em infecções por $C$. psittaci há excreção intermitente do corpo elementar, particularmente em aves assintomáticas, o que favorece a ocorrência de resultados falso-negativos (Harkinezhad et al., 2009; Vázquez et al., 2010).

Nas amostras positivas pela PCR em tempo real, observou-se ciclo limiar (treshold cycle - $\mathrm{Ct}$ ) variando de 29,68 a 42,93. Foi observada positividade em 4,21\% (17/403) das amostras, sendo 16 pertencentes a aves da ordem Psitaciformes: 12 Nymphicus hollandicus, duas 
Amazona aestiva, duas Trichoglossus $h$. haemadus e uma ave da ordem Piciformes: Ramphastos tucanus (Tab. 2). Doze amostras foram provenientes de um criatório de psitacídeos, três de um zoológico e duas de aves provenientes de apreensão.

A positividade para infecção por $C$. psittaci é variável em função de situações que predispõem as aves à infecção, presença de enfermidade clínica e ao teste diagnóstico utilizado (Stewardson e Grayson, 2010; Okuda et al., 2011). Há relatos desde positividade de $6,3 \%$ (2/32) em papagaios-verdadeiros (A. aestiva) e de 26,7\% (12/45) em araras-azuis (Anodorhynchus hyacinthinus), procedentes de aves jovens do Pantanal do Mato Grosso do Sul, Brasil (Raso et al., 2006), 52,6\% (61/116) em pombos na Espanha (Vázquez et al., 2010) e 90\% (43/47) em várias espécies de aves de gaiola na Turquia (Sareyyupoglu et al., 2007).

A hemi-nested PCR revelou amplificação de DNA de Chlamydophila em duas amostras de Nymphicus hollandicus (Tab. 4), entre aquelas positivas pela PCR em tempo real. As duas foram provenientes do mesmo criatório. Foi possível o sequenciamento de uma amostra, o que permitiu a identificação do genótipo $\mathrm{A}$ de $C$. psittaci. Em estudo realizado por Mitchell et al. (2009), $70 \%$ das amostras positivas para Chlamydophila spp. foram identificadas como genótipo A de $C$. psittaci, que é comumente identificado em amostras de psitacídeos (Geens et al., 2005a).

Foi realizado também o sequenciamento do fragmento de $818 \mathrm{pb}$ da subunidade $16 \mathrm{~S}$ do rRNA, amplificado a partir do DNA de $C$. abortus, que foi utilizado como controle positivo; nesse fragmento foi observado, na região correspondente ao fragmento interno de $151 \mathrm{pb}$ que foi amplificado pela PCR em tempo real, polimorfismo de cinco nucleotídeos em relação às sequências de DNA de $C$. psittaci publicadas no GenBank (AF481051 e AF481052) (Tab. 3). Esse polimorfismo resultou na pequena diferença na variação da temperatura observada na curva de dissociação, entre a amostra de $C$. abortus e o isolado de $C$. psittaci genótipo A, identificado em amostra fecal de uma N. hollandicus (Fig. 1).

Como não há diferença na temperatura de dissociação suficiente para permitir a diferenciação entre $C$. abortus e $C$. psittaci, não foi possível identificar a espécie de Chlamydophila presente nas amostras positivas pela PCR em tempo real e que não foram identificadas pelo sequenciamento. Mesmo assim, a maior probabilidade é de que haja presença de $C$. psittaci nessas amostras, uma vez que a infecção por $C$. abortus raramente é relatada em aves (Chahota et al., 2006; Pantchev et al., 2009).

Tabela 3. Região de anelamento dos oligonucleotídeos iniciadores utilizados na PCR em tempo real, em sequências de Chlamydophila spp.

\begin{tabular}{|c|c|c|}
\hline $\begin{array}{l}\text { Espécie de } \\
\text { Chlamydophila }\end{array}$ & $\begin{array}{c}\text { Identificação } \\
\text { no } \\
\text { GenBank } \\
\end{array}$ & Alinhamento \\
\hline & & 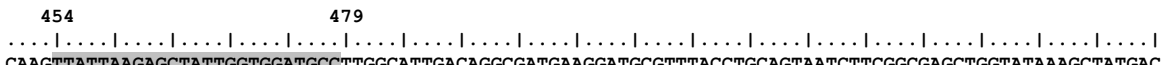 \\
\hline $\begin{array}{l}\text { C. psittaci } \\
\text { C. abortus }\end{array}$ & AF481051 & CAAGTTATTAAGAGCTATTGGTGGATGCCTTGGCATTGACAGGCGATGAAGGATGCGTTTACCTGCAGTAATCTTCGGCGAGCTGGTATAAAGCTATGAC \\
\hline $\begin{array}{l}\text { C. abortus } \\
\text { C. abortus }\end{array}$ & U68446 & (n. \\
\hline $\begin{array}{l}\text { cepa } S 23 / 3 \\
\text { C. caviae }\end{array}$ & U68451 & $\ldots \ldots$ G.............. \\
\hline C. felis & U68458 & 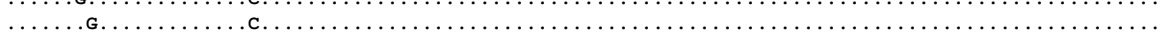 \\
\hline C. pneumoniae & U76711 & \\
\hline C. pecorum & U68439 & 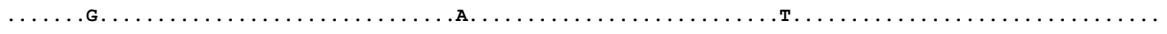 \\
\hline & & 573 \\
\hline C. psittaci & AF481051 & $\begin{array}{l}\ldots,|\ldots| \ldots|\ldots| \ldots|\ldots| \ldots|\ldots| \ldots|\ldots| \ldots|\ldots| \ldots, \ldots 1 \ldots 1 \ldots \\
\text { CCGGAGGTCTCCGAATGGGGCAACCCGGTAGATTAATCATCTACCATTATACGTTGAAT }\end{array}$ \\
\hline C. abortus & U68446 & 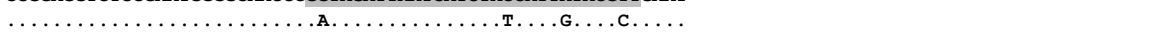 \\
\hline C. abortus & - & А...................... \\
\hline $\begin{array}{l}\text { S23/3 } \\
\text { C. caviae }\end{array}$ & U68451 & $\ldots \ldots$ А. $\ldots \ldots \ldots$ т. $\ldots \ldots \ldots \ldots \ldots$ G. $\ldots \ldots \ldots$ тАС. $\ldots$ \\
\hline C. felis & U68458 & 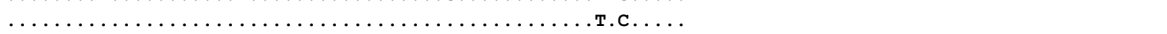 \\
\hline C. pneumoniae & U76711 & 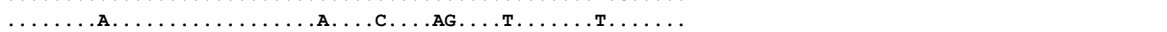 \\
\hline C. pecorum & U68439 & $\ldots \ldots \ldots$ т. $\ldots \ldots \ldots$ АA $\ldots \ldots$ А. $\ldots \ldots$ АG. $\ldots$ т. $\ldots \ldots \ldots$ с. $\ldots$ \\
\hline
\end{tabular}


Tabela 4. Determinação do genótipo de Chlamydophila psittaci por meio de hemi-nested PCR e sequenciamento dos fragmentos amplificados, em amostras fecais de aves positivas pela PCR em tempo real

\begin{tabular}{lccc}
\multicolumn{1}{c}{ Espécie } & $\begin{array}{c}\text { Amostras positivas } \\
\text { pela PCR em tempo } \\
\text { real }\end{array}$ & $\begin{array}{c}\text { Amostras positivas } \\
\text { pela hemi-nested PCR }\end{array}$ & $\begin{array}{c}\text { Identificação do genótipo } \\
\text { (número de amostras) }\end{array}$ \\
$\begin{array}{l}\text { Amazona aestiva } \\
\begin{array}{l}\text { Nymphicus } \\
\text { hollandicus } \\
\text { Ramphastus tucanus }\end{array}\end{array}$ & 2 & - & - psittaci genótipo A (1) \\
$\begin{array}{l}\text { Trichoglossus } h . \\
\text { haemadus }\end{array}$ & 12 & 2 & - \\
& 2 & - & - \\
\hline Total & 1 & & - \\
\hline
\end{tabular}

Geens et al. (2005a) relatam que os oligonucleotídeos iniciadores utilizados neste experimento, para realização da PCR em tempo real, são específicos para $C$. psittaci, mas que também amplificam DNA de $C$. caviae, com ciclo limiar acima de 37, e não amplificam DNA de C. abortus ou de outras espécies de Chlamydophila. No entanto, neste experimento foi possível a amplificação de fragmentos de DNA de C. abortus, com ciclo limiar de aproximadamente 20, apesar de haver polimorfismo entre sequências de $C$. abortus e $C$. psittaci, na região de anelamento dos oligonucleotídeos iniciadores utilizados na PCR em tempo real (Tab. 3). Dessa maneira, a possibilidade de amplificação inespecífica durante a utilização de diagnóstico molecular de infecção por $C$. psittaci, utilizando amplificação de sequências da subunidade $16 \mathrm{~S}$ do gene rRNA, deve ser analisada com critério.

Infecção por $C$. psittaci já foi identificada em psitacídeos (Raso et al., 2002; 2004; 2006) e pombos no Brasil (Lima et al., 2011), sendo que algumas das amostras de psitacídeos foram identificadas como genótipo A de C. psittaci (Raso, 2012, FMVZ-USP, comunicação pessoal).

\section{CONCLUSÕES}

Os resultados deste experimento demonstram que a PCR em tempo real, visando à amplificação de fragmento parcial da subunidade $16 \mathrm{~S}$ do rRNA seguida da análise da curva de dissociação, pode ser utilizada para detecção de DNA de Chlamydophila sp. em amostras fecais de aves assintomáticas. A classificação da espécie de Chlamydophila e do genótipo de $C$. psittaci deve ser realizada por meio de PCR, tendo como alvo o gene ompA e sequenciamento dos fragmentos amplificados.

\section{REFERÊNCIAS}

CHAHOTA, R.; OGAWA, H.; MITSUHASHI, Y. et al. Genetic diversity and epizootiology of Chlamydophila psittaci prevalent among the captive and feral avian species based on VD2 region of ompA gene. Microbiol. Immunol., v.50, p.663-678, 2006.

DENAMUR, E.; SAYADA, C.; SOURIAU, A. et al. Restriction pattern of the major outer membrane protein gene provides evidence for a homogeneous invasive group among ruminant isolates of Chlamydia psittaci. J. Gen. Microbiol., v.137, p.2525-2530, 1991.

GEENS, T.; DEWITTE, A.; BOON, N. et al. Development of a Chlamydophila psittaci species-specific and genotype-specific real-time PCR. Vet. Res., v.36, p.787-797, 2005a.

GEENS, T.; DESPLANQUES, A.; VAN LOOCK, M. et al. Sequencing of the Chlamydophila psittaci ompA gene reveals a new genotype, $\mathrm{E} / \mathrm{B}$, and the need for a rapid discriminatory genotyping method. J. Clin. Microbiol., v.43, p.2456-2461, 2005 b.

HARKINEZHAD, T.; GEENS, T.; VANROMPAY, D. Chlamydophila psittaci infections in birds: A review with emphasis on zoonotic consequences. Vet. Microbiol., v.135, p.68-77, 2009. 
HEDBERG K.; WHITE K.E.; FORFANG J.C. et al. An outbreak of psittacosis in Minnesota turkey industry workers: implications for modes of transmission and control. Am. J. Epidemiol., v.130, p.569-577, 1989.

HINTON, D.G.; SHIPLEY, A.; GALVIN, J.W. et al. Chlamydiosis in workers at a duck farm and processing plant. Aust. Vet. J., v.70, p.174176,1993

KALETA, E.F.; TADAY, E.M. Avian host range of Chlamydophila spp. based on isolation, antigen detection and serology. Avian Pathol., v.32, p.435-461, 2003.

LIMA, V.Y.; LANGONI, H.; SILVA, A.V. et al. Chlamydophila psittaci and Toxoplasma gondii infection in pigeons (Columba livia) from São Paulo State, Brazil. Vet. Parasitol., v.175, p.914, 2011.

MILLER, C.D.; SONGER, J.R.; SULLIVAN, J.F. A twenty-five year review of laboratoryacquired human infections at the National Animal Disease Center. Am. Ind. Hyg. Assoc. J., v.48, p.271-275, 1987.

MITCHELL, S.L.; WOLFF, B.J.; THACKER, W.L. et al. Genotyping of Chlamydophila psittaci by real-time PCR and high-resolution melt analysis. J. Clin. Microbiol., v.47, p.175$181,2009$.

OKUDA, H.; OHYA, K.; SHIOTA, Y. et al. Detection of Chlamydophila psittaci by using SYBR green real-time PCR. J. Vet. Med. Sci. v.73, p.249-254, 2011.

PANTCHEV, A.; STING, R.; BAUERFEIND, R. et al. New real-time PCR tests for speciesspecific detection of Chlamydophila psittaci and Chlamydophila abortus from tissue samples. Vet. J., v.181, p.145-150, 2009.

PROENÇA, L.M.; FAGLIARI, J.J.; RASO, T.F. Infecção por $C$. psittaci: uma revisão com ênfase em psitacídeos. Cienc. Rural, v.41, p.841-847, 2011.
RASO, T.F.; BERCHIERI, JR.A.; PINTO, A.A. Evidence of Chlamydophila psittaci infection in captive Amazon parrots in Brazil. J. Zoo Wildl. Med., v.33, p.118-121, 2002.

RASO, T.F.; GODOY, S.N.; MILANELO, L. et al. An outbreak of chlamydiosis in captive Bluefronted Amazon parrots (Amazona aestiva) in Brazil. J. Zoo Wildl. Med., v.35, p.94-96, 2004.

RASO, T.F.; SEIXAS, G.H.F.; GUEDES, N.M.R. et al. Chlamydophila psittaci in freeliving blue-fronted amazon parrots (Amazona aestiva) and hyacinth macaws (Anodorhynchus hyacinthinus) in the Pantanal of Mato Grosso do Sul, Brazil. Vet. Microbiol., v.117, p.235-241, 2006.

SAREYYUPOGLU, B.; CANTEKIN, Z.; BAS, B. Chlamydophila psittaci DNA detection in the faeces of cage birds. Zoon. Pub. Health, v.54, p.237-242, 2007.

SHEWEN, P.E. Chlamydial infection in animals: a review. Can. Vet. J., v.21, p.2-11, 1980.

SILVA, C.D.; HOMEM, C.G.; NAKAMURA, A.N. et al. Physical, epidemiological, and molecular evaluation of infection by Cryptosporidium galli in Passeriformes. Parasitol. Res., v.107, p.271-277, 2010.

STEWARDSON, A.J.; GRAYSON, M.L. Psittacosis. Infect. Dis. Clin. N. Am., v.24, p. 725,2010 .

VANROMPAY, D.; BUTAYE, P.; SAYADA et al. Characterization of avian Chlamydia psittaci strains using ompl restriction mapping and serovar-specific monoclonal antibodies. Res. Microbiol., v.148, p.327-333, 1997.

VÁZQUEZ, B.; ESPERÓN, F.; NEVES, E. et al. Screening for several potential pathogens in feral pigeons (Columba livia) in Madrid. Acta Vet. Scand., v.52, p.1-6, 2010. 